\title{
Correction: Diabetic ketoacidosis at the onset of disease during a national awareness campaign: a 2-year observational study in children aged 0-18 years
}

Rabbone I, Maltoni G, Tinti D, et al. on behalf of the Diabetes Study Group of the Italian Society for Pediatric Endocrinology and Diabetology (ISPED). Diabetic ketoacidosis at the onset of disease during a national awareness campaign: a 2-year observational study in children aged 0-18 years. Arch Dis Child 2020;105:363-6. doi:10.1136/archdischild-2019-316903

In the list of collaborators, two authors were mis-named. Their correct names are Fortunato Lombardo and Giuseppina Salzano.

(C) Author(s) (or their employer(s)) 2021. No commercial re-use. See rights and permissions. Published by BMJ. Arch Dis Child 2021;106:e39. doi:10.1136/archdischild-2019-316903corr1

(D) Check for updates 